\title{
NOTES
}

\section{RELEASED TIME RECONSIDERED: THE NEW YORK PLAN IS TESTED*}

The First Amendment, ${ }^{1}$ made applicable to the states by the Fourteenth Amendment," prohibits state and national laws "respecting an establishment of religion." It aims to promote religious freedom for all by keeping government independent of the varied religious rivalries in the community. ${ }^{3}$ In the Everson ${ }^{4}$ and $\mathrm{MCCollum}^{5}$ cases the Supreme Court interpreted the Amendment to interdict laws which establish a church, aid one or all religions, or levy taxes to support religious activities and institutions. Furthermore, government may not influence a person's decision whether or not to go to church or what type of religious belief, if any, to hold. ${ }^{6}$ Thus, the Constitution today goes further than prohibiting the establishment of a state church; it endeavors to keep religion and the state separate. ${ }^{7}$

*Zorach v. Clauson, 303 N.Y. 161, 100 N.E. $2 d 463$ (1951), prob. juris. noted 20 U.S.L. WEEK 3154 (1952).

1. "Congress shall make no law respecting an establishment of religion, or prohibiting the free exercise thereof . . " U.S. Const. AxrEns. I.

2. Hamilton v. Board of Regents, 293 U.S. 245 (1934), and West Virginia State Board of Education v. Barnette, 319 U.S. 624 (1943) (free exercise of religion); Everson v. Board of Education, 330 U.S. 1 (1947), and Illinois ex rel. McCollum v. Board of Education, 333 U.S. 203 (1948) (no establishment of religion).

3. Id. at 227. See also id. at 212, 215, 216, 232; Everson v. Board of Education, 330 U.S. 1, 40, 59 (1947).

4. Everson v. Board of Education, 330 U.S. 1 (1947) (publicly financed school bus transportation for parochial students upheld against challenge that it vas unconstitutional aid by the state in support of religion). See Notes, 49 Cot. L. REv. 836 (1949) ; 60 HARv. L. Rev. 793 (1947) ; 96 U. PA. L. Rev. 230 (1947).

5. Illinois ex rel. MicCollum v. Board of Education, 333 U.S. 203 (1948) (released time program, in which children could obtain religious instruction during public school time on school property, declared an unconstitutional aid to religion). See Notes, 43 ILL L. Rev. 374 (1948) ; 23 Notre Dasie Law. 456 (1948); 57 Yale L. J. 1114 (1948).

6. "Neither a state nor the Federal Government can set up a church. Neitber ean pass laws which aid one religion, aid all religions, or prefer one religion over another. Neither can force or influence a person to go to or to remain away from church against his will or force him to profess a belief or disbelief in any religion. No person can be punished for entertaining or professing religious beliefs or disbeliefs, for church attendance or non-attendance. No tax in any amount, large or small, can be levied to support any religious activities or institutions, whatever they may be called, or whatever form they may adopt to teach or practice religion. Neither a state nor the Federal Government can, openly or secretly, participate in the affairs of any religious organizations or groups and vice versa. In the words of Jefferson, the clause against establishment of religion by law was intended to erect 'a wall of separation between Church and State." Black, J., in Everson v. Board of Education, 330 U.S. 1, 15-16 (1947); reaffirmed in Illinois ex rel. McCollum v. Bard of Education, 333 U.S. 203, 210-11, (1948).

7. Some writers dispute the validity of the Supreme Court's interpretation of the First Amendment. They argue that the First Amendment was intended only to prevent 
The First Amendment also protects religious freedom by prohibiting government hostility to religion or interference with its free exercise. ${ }^{8}$ Accordingly, the right of people to practice ${ }^{9}$ and propagate ${ }^{10}$ religious beliefs is sufeguarded. This includes freedom to abstain or dissent from any or all religious identifications. ${ }^{11}$

The policies embodied in these two First Amendment prohibitions, although directed toward the same goal, in practice may sometimes conflict. ${ }^{12}$ Thus, in allowing to religious groups the tax exemption generally available for charitable institutions, ${ }^{13}$ government may be observing the prohibition against

the government from establishing one sect in a preferred position, but it does not prevent general support by government for religion on a non-discriminatory basis. Sce O'NEAL, Retigion and Education Under the Constitution (1949); Parsons, Tue First Freedom (1948); Corwin, The Supreme Court As National School Board, 14 LAW \& Contemp. Prob. 3 (1949); Fahy, Religion, Education and the Supreme Court, 14 LAw \& Contemp. Prob. 73 (1949); Murray, Law or Prepossessions?, 14 Law \& Content. Pron. 23 (1949). The interpretation given the First Amendment by the Supreme Court has been ably defended by other scholars. See Pfeffer, Church and State-Something Less Than Separation, 19 U. of Chi. L. Rev. 1 (1951); Butrs, Tue American Tradition in Rejigton and Education (1950); Stokes, Church and State in the United States (1950).

8. At Madison's insistence, the Virginia Bill of Rights read: "All men are equally entitled to the free exercise of religion, according to the dictates of conscience." This was the first time that this right had been asserted in any body of fundamental law. Id. at 341 . The "Memorial and Remonstrance" of 1784 written by Madison repeated this right. And Madison's demands were largely responsible for the religious guarantees of the First Amendment. Id. at 345. For a full discussion of the Federal Constitutional provisionts see id., at c. 8.

9. West Virginia State Board of Education v. Barnette, 319 U.S. 624 (1934) (children cannot be compelled to salute the flag contrary to their religious beliefs). But cf. Reynolds v. United States, 98 U.S. 145 (1878), and Davis v. Beason, 133 U.S. 333 (1890) (Mormons' religious belief in polygamous marriage not given protection).

10. Religious missionaries may distribute handbills, Schneider v. New Jersey, 308 U.S. 147 (1939), even in a privately owned company town, Marsh v. Alabama, 326 U.S. 501 (1946). And the state may not prohibit door to door distribution of religious literature, Martin v. Struthers, 319 U.S. 141 (1943). Nor may municipal officials be given discretionary power to grant or withhold permits for public religious meetings, Niemotko v. Maryland, 340 U.S. 268 (1951).

11. Agnostics and athiests are protected by the First Amendment. Illinois ext rel. McCollum v. Board of Education, 333 U.S. 203 (1948) (free thinker's challenge of state aid to religion sustained). But see PARsons, THE FIRST FREedoM 79 (1948); Zorach v. Clauson, 99 N.Y.S. $2 d$ 339, 344 (1950), and White, J., concurring in Gordon v. Board of Education, $78 \mathrm{Cal}$. App. 2d 464, 476-80 (1948).

12. The conflicting nature of the free exercise and no establishment clauses of the First Amendment are suggested in Everson v. Board of Education, 330 U.S. 1, 16, 18 (1947); and Illinois ex rel. McCollum v. Board of Education, 333 U.S. 203, 211-12 (1948). See Pfeffer, supra note 7, at 23; Murray, supra note 7, at 32-41; Fahy, stupra note 7, 88-90; Note, 49 CoL. L. Rev. 968, 988-90 (1949).

13. Exempted from Federal income tax are corporations, funds, and foundations "operated exclusively for religious, charitable, scientific, literary or educational purposes." INT. REV. CODE $\S 101(6)$; "Religious or apostolic associations or corporations . . . even if such associations or corporations engage in business for the common benefit of the 
hostility to religion, ${ }^{14}$ but at the same time it may encroach on the no aid policy. Similarly conflict results when government tries to make provision for the free exercise of religion. Examples are: furnishing military chaplains, ${ }^{15}$ daily bible reading in the public schools, ${ }^{16}$ and released time religious instruction. ${ }^{17}$

members. .. ." INT. Rev. CoDE $\$ 101$ (1S); and "corporations organized for the exclusive purpose of holding title to property, collecting income therefrom, and turning over the (net income) ... to an organization which itself is exempt from the tax." I:rr. Rev. CODE $\$ 101$ (14). Gifts to religious organizations are exempt from gift tax, I:T. REv. CODE $\$ 1004$ (a) (2), and estate tax, INT. REv. CONE $\$ \$ 12$ (d), and may be deducted from the income of the donor, INT. Rev. CoDE $\& 23$ (o) (2), Init. REv. Cons $\$ 23$ (q) (2). State income taxes provide the same exemptions, e.g., CAI. Rev. \& TAx Covz $\S 17315$ (6) (Deering 1944) ; N.Y. TAX LAw $\$ 360$, (10) (b). General property tax exemptions for religious organizations are available in all states, c.g. CAL. REv. \& TAX Corz $\S 206$ (Deering 1944); N.Y. TAX LAW \& 4 (6), and are considered important enough to be guaranteed by the Constitutions of two-thirds of the states, c.g., FLA. Co:ssr. Arr. XVI, sec. 16; N.M. Const. Art. VIII; Caltr. Const. Art. XIII \$1 1/2; See Torper, Judicial Doctrines of Rezigious Rights in Adrenica 173 n. 10 (1948). Tax exemption for religious organizations is discussed in Paulson, Preferntent of Religions Institutions in Tax and Labor Legislation, 14 LAW \& Contesr. Prob. 144 (1949).

14. Some taxes cannot be levied against religious activities, even where non-religious groups engaged in the same type of activity must pay the tax. MIurdock v. Pa, 319 U.S. 105 (1943) (distributor of religious pamphlets exempt from local license tax) overruling Jones v. Opelika, 316 U.S. 584 (1942); Follett v. Town of MfcCormicl, 321 U.S. 573 (1944). Thus, a fortiori a tax upon religious groups not applied to other groups engaging in similar activities, would be invalid. Of course, some forms of taxes relating to religion, such as income and property taxes on preachers, are permissible. Id. at 577-8. Cf. Murdock case, supra, at 108-9.

15. Government expenditures for religious institutions in military establishments include chaplains and chapels at West Point, Annafolis, e.g., 29 Stat. 8 c. 22 (1896), 10 U.S.C. $\$ 1083$ (1946), and in the Armed services, 64 Stat. 270 (1950), 10 U.S.C.A. § 2313 (1951 Supp.), 13 Stat. 46 (1864), 10 U.S.C. § 238 (1946) (Army); R.S. \$§ 1396-7, 34 U.S.C. $\$ \$ 91,95$ (1946) (Navy). Madison believed chaplaincies in the armed forces to te violative of the First Amendment. Fleet, Madison's "Delached Menuoranda," 3 Wuxuss \& MIARY Q. 534, 559 (3d ser., 1946), reported in Pfeffer, supra note 7, at 12.

16. Bible reading in the public schools was upheld in Doremus v. Board of Edueation, 5 N.J. 435, 75 A.2d 880 (1950) prob. juris. noted 19 L.W. 3244 (1950). Accord: Donohue v. Richards, 38 Me. 379 (1854); Hackett v. Broolsville, 120 Ky. 60S, 87 S.W. 792 (1905) ; People v. Stanley, 81 Colo. 276, 255 Pac 610 (1927). Contra: State v. District Board, 76 Wisc. 177, 44 N.W. 967 (1890) ; State v. Scheve, 65 Neb. 853, 91 N.W. \&6 (1902); People v. Board of Education, 245 III. 333, 92 N.E. 251 (1910). See ToRpEx, op. cit. supra note 13 at 244-49; II Stokes, op. cit. supra note 7, at 549-72.

17. Released time is an extensive practice in the United States. In 1947 it involved

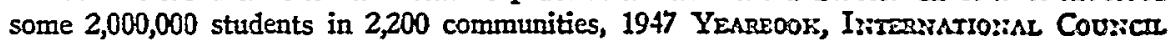
of Religious Education 76 (1947). A study of released time practice since the AfC Collum decision indicates that of the school systems reporting which had ever had a released time program, only $11.8 \%$ had discontinued it; half of them due to the MfCollum decision. National Education Association, The Status of Religious Educhtiozi im tar Public Schools 9, 14 (1949). Various techniques for released time programs include (1) formal classes in religious education taught in the public school buildings during regular school hours and involving official cooperative relationships between the school 
Zorach v. Clauson ${ }^{18}$ confronts the Supreme Court with a case involving this internal conflict in the First Amendment. Parents whose children receive religious instruction outside of school time are challenging the constitutionality of New York's released time program. ${ }^{10}$ Under the program a child may be excused from his regularly scheduled classes for one hour a week to attend religious classes held off public school property. ${ }^{20}$ This

and church groups; (2) pupils excused during school hours to attend religious educttion classes outside of school building and attendance is reported to the public school; and (3) same as (2) only school has no responsibility for the administration of the program. For statistical study of the frequency of the systems see id. at 8-14.

18. 303 N.Y. 161, 100 N.E. 2d 463 (1951). The lower court opinions, 198 Misc. 631, 99 N.Y.S. 2d 339, 278 App. Div. 573, 102 N.Y.S. 2d 27, were noted in: 49 CoL. L. Rev. 836 (1949), 14 Detroit L. Rev. 216 (1951), 39 Geo. L.J. 148 (1950), 25 ST. Joun's L. Rev. 91 (1950), 20 U. of Cin. L. Rev. 297 (1951).

19. The children of the petitioners attended religious classes outside of public school hours-Zorach's child at a Protestant Episcopal religious school and Gluck's children at a Jewish religious school, Zorach v. Clauson, 303 N.Y. 161, 184 (1950) (dissenting opinion).

20. The Education Law of New York provides: "Absence for religious observance and education shall be permitted under rules that the commissioner [the State Commissioner of Education] shall establish." N.Y. Laws 1940, c. 305; N.Y. Ev. LAw § 3210, 1-b. The rules which the State Commissioner of Education promulgated provide:

"1. Absence of a pupil from school during school hours for religious observance and education to be had outside the school building and grounds will be excused upon the request in writing signed by the parent or guardian of the pupil.

"2. The courses in religious observance and education must be maintained and operated by or under the control of a duly constituted religious body or of duly constituted religious bodies.

"3. Pupils must be registered for the courses and a copy of the registration filcd with the local public school authorities.

"4. Reports of attendance of pupils upon such courses shall be filed with tho principal or teacher at the end of each week.

"5. Such absence shall be for not more than one hour each week at the close of a session at a time to be fixed by the local school authorities.

"6. In the event that more than one school for religious obscrvance and cducation is maintained in any district, the hour for absence for each particular public school in stuch district shall be the same for all such religious schools."

Regulations of the Comr. of Education, Art. 17, $\S 154$; State of N.Y. Official Compilation of Codes, Rules and Regulations, Vol. 1, p. 683.

In addition the New York City Board of Education provided:

"1. A program for religious instruction may be initiated by any religious organization, in cooperation with the parents of pupils concerned. There will be no announcement of any kind in the public schools relative to the program.

"2. When a religious organization is prepared to initiate a program for religious instruction, the said organization will notify parents to enroll their children with the religious organization, and will issue to each enrolled pupil a card countersigned by the parent and addressed to the principal of the public school, requesting the release of the pupil from school for the purpose of religious instruction at a specific location. The said cards will be filed in the office of the public school as a record of pupils entitled to be excused, and will not be available for any other purpose.

"3. Religious organizations, in cooperation with parents, will assume full responsibility for attendance at the religious center and will file with the school principal weekly, at 
release is made upon the request of a parent and a "duly constituted religious body prepared to initiate a program of religious instruction."

The New York Court of Appeals upheld released time despite the Supreme Court's prior invalidation of a similar program in Champaign, Illinois." There the instruction was on school property and was indirectly supervised by school authorities. The New York court held that the lesser amount of school support in the New York program constitutionally distinguished it from the Champaign plan, ${ }^{22}$ and it felt bound by earlier New York precedent upholding a similar program. ${ }^{23}$ The court argued that elimination of the program would impair parents' right to direct the rearing and education of their children.

Released time is thus attacked as aid and justified as free exercise. By emphasizing free exercise, the New York court upheld the statute. On the

card attendance record and in cases of absence from religious instruction, a statement of the reason therefor.

"4. Upon the presentation of a proper request as above prescribed, pupils of any grade will be dismissed from school for the last hour of the day's session on one day of each week to be designated by the superintendent of schools; a different day may be designated for each borough.

"5. Pupils released for religious instruction will be dismissed from school in the usual way and the school authorities have no responsibility beyond that assumed in regular dismissals.

"6. There shall be no comment by any principal or teacher on the attendance or nonattendance of any pupil upon religious instruction."

Issued November 13, 1940 and amended September 24, 1941. Reported in Papers on appeal in Zorach v. Clauson to N.Y. Court of Appeals, folio 86-95 (hereafter cited as PAPERS ON APPEAL).

21. Illinois ex rel. AIcCollum v. Board of Education, 333 U.S. 203 (1948).

22. "It is manifest that the McCollum case is not a holding that all released time programs are per se unconstitutional." Zorach v. Clauson, 303 N.Y. 161, 169, 100 N.E. 463,465 (1951). A similar narrow construction of the $\mathrm{ArcC}$ ollum case was talien by the Attorneys General in California, Nevada, Oregon, Pennsylvania, South Dakot3, Virginia,

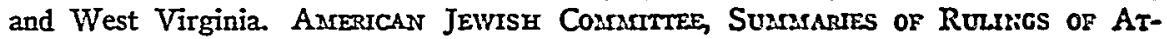
torneys General with respect of Church-State Questions as they Affect Pudlic and Parochial Schoors, March 23, 1951. Only a small percentage of the weekday church schools have stopped functioning as a result of the MfCollum decision. According to one study, Natronal Public Education Assoctation, The Status of Reurgious Enucation in the Public Sczools (1949), 6\% of the communities reporting had discontinued their program due to the MICCollum decision and another $8 \%$ had altered their programs to exclude religious classes from the public school buildings. Another source indicates that less than $10 \%$ of the released time programs were discontinued due to MICCollinn. Announced by the International Council of Religious Education in February, 1949, reported in BUTTs, op. cit. stpra note 7, at 202-3. A broader view of the MicCollssm holding was taken by the United States Department of Interior, supervising Indian schools, and the Attorneys General in Colorado, Kansas Indiana, and Wisconsin have interpreted the $\mathrm{McCollum}$ case to exclude released time programs such as that in Nev York. AMrerican Jewish CoMantTEE, op. cit. supra.

23. People ex rel. Lewis v. Graves, 245 N.Y. 195, 156 N.E. 663 (1927) (released time program in White Plains, New York, upheld). 
other hand, stress upon aid could just as logically compel a holding of unconstitutionality. In deciding on which of the two religious clauses of the First Amendment to rely, a court actually determines the controversy. This procedure is inadequate because it does not provide a framework for inquiry into the relevant facts affecting the overall policy of the First Amendment.

A more desirable way to resolve the conflict is to compare the impact upon one right resulting from one alternative decision with the effect upon the competing right if the opposite decision were rendered. The released time program must be studied in its operation. To determine the encroachment upon the no aid principle, the amount and effect of actual state aid to religion involved must be ascertained. Against this must be balanced the restraint upon the free exercise which would result if the program were invalidated. Thus, by indicating whether a greater danger to religious freedom exists in state interference or state aid, the fundamental objective of the First Amendment-to prevent state encroachment from either direction-is promoted.

If the released time program were invalidated, the resulting restraint upon free exercise would be the inability of parents who so desired to have religious instruction given to their children during one hour of public school time weekly. Courts have usually allowed parents, in the exercise of their religious freedom, reasonably to control the education of their children. ${ }^{24}$ But here the restraint on parents' freedom is lessened by the availability of alternative courses of action. A parent may still elect to send his child to a private religious school. ${ }^{25}$ This may, however, be an onerous alternative where he is already supporting the public school system with taxes, and may not be feasible for the parent whr cannot afford the added cost of a private school. ${ }^{26}$ A second possibility is for the parent to provide religious

24. Parents have a constitutional right to have their children excused from bible reading in the public school. People ex rel. Vollman v. Stanley, 81 Colo. 276, 255 Pac. 610 (1927); State ex rel. Finger v. Weedman, 55 S.D. 343, 226 N.W. 348 (1929). Scc also Hardwick v. Board, 54 Cal. App. 696, aff'd, 54 Cal. App. 714, 205 Pac. 56 (1921) (child excused from dancing lessons where religious beliefs forbade dancing). But the state can make some reasonable requirements that are contrary to religious beliefs. Rice v. Commonwealth, 188 Va. 224, 49 S.E. $2 d 343$ (1948) (compulsory education law enforced over parents' claim that their religious beliefs dictated that the parent must tcach his own child). See cases, infra note 25.

25. Pierce v. Society of Sisters, 268 U.S. 510 (1925). Cf. Meyer v. Nebraska, 262 U.S. 390, 399-402 (1923) (parents' right to control the education of their child).

A recent survey reports 10,071 private elementary schools and 3,292 private sccondary schools in the country. Office of Education, Biemnial Survey of Education in the United States 1946-48 c. 1 (1950). No figures are available as to what percent of the private elementary schools are denominational, but $81 \%$ of the private secondary schools are denominational. Id. at c. 7 .

26. A survey of the cost of denominational schools in New Haven indicated that tuition per year, exclusive of laboratory fees, typing costs, and text book charges for high schools is: St. Mary's, $\$ 150.00$; Notre Dame, $\$ 170.00$. Scholarships are available for athletic ability and intelligence. Priests of some parishes pay the tuition for some children. Elementary school fees are: St. Mary's, no tuition for those in the parish, $\$ 2.00$ a month for those outside; St. Aedan's, $\$ 10.00$ a family a year for those in the parish. 
education, such as Sunday School instruction, for his children during nonschool hours. The public school takes about thirty-five hours in the week,, 7 leaving ample time for religious instruction. Thus, the elimination of the program would not prevent the full expression of parental preference that their children obtain religious education, although it would constitute some restriction on parents' freedom of choice.

Continuance of released time would sanction infringement of the "separation doctrine" by state aid existing in three aspects of the program's operation. One element of aid is the New York Education Law. It requires through its truancy provisions that those students who are released actually attend their religious classes. ${ }^{28} \mathrm{~A}$ released child who fails to attend religious classes has no excused absence from public school and is thus a truant..0 In enforcing the truancy law upon released time truants some school districts interview the child to find out why he did not attend the religious instruction. ${ }^{30}$ Other districts, if the child is frequently truant, refuse him permission to be released for religious instruction. ${ }^{31}$ Still others use these techniques jointly. ${ }^{32}$ In addition to the actual enforcement sanctions, the very

27. Computed on the basis of a five-day school week with classes from 8:30 A.M. to $3: 30$ P. M.

28. The New York Education Law provides that each minor from 7 to 16 years of age shall attend school, N.Y. Ev. LAW $\$ 3205$ (L), and that he shall be excused only for causes allowed by the general rules and the practices of the public schools. Id. at $\$ 3210$ (2) (b). The teachers and principals are responsible for keeping an attendance record of every child for each day and hour of the school year. Id. at \$3211. The Commissioner of Education is responsible for supervising the overall enforcement of the truancy provisions. Id. at $\$ 3229$. Jail sentences or fines can be levied against those who violate the Education Law. Id. at $\$ 3228$.

29. Statement of the Soliciter General for the State of New York in oral argument before the Appellate Division Court. Referred to in Reply Brief for PetitionersAppellants, Court of Appeals, p. 38.

Students have excused absences only if they attend religious classes; otherwise the absence is unexcused. N.Y. Ev. LAw $\$ 3210$. Also see Rules 1 and 4 of the Regulations of the Commissioner of Education, and Rule 3 of the Regulations issued by the Board of Education of the City of New York, supra note 20.

30. Letter from David Bray, Chief of Bureau of Child Accounting, Enforcement and Census, City of Albany to Mr. John Park, Superintendent of Schools, Albany, New York, May 14, 1948. Papers on Appeal folio 172-9.

31. Letter from Harold French, Superintendent of Schools, Newtonville, New York, to Mr. Charles Brind, Counsel and Assistant Conmissioner, State Edueation Department, Mray 13, 1948. Papers on Appeal folio 166-71.

32. Letter from Kenneth MacFarland, Superintendent of Schools, Rensselaer, New York, to Mr. Charles Brind, Counsel and Assistant Commissioner, State Education Department, Miay 13, 1948. Papers on Appeal folio 181-6.

Rule 3 of the regulations of the Board of Education in New York City instructs the schools, in effect, not to enforce the truancy law, and places the primary responsibility for attendance at the religious center on the parents and the religious organizations operating the classes. See note 20 supra. However the added requirement that the religious center file attendance cards with the principal is contradictory to the provision placing full responsibility for attendance on the religious organization and parents. Rule 3 , Regulations of the N.Y.C. Board of Education and Rule 4, Regulations of the State 
existence of the law may influence the released child to attend his religious classes. ${ }^{33}$ Use of the compulsory education law in a released time program was expressly condemned in the McCollum decision. ${ }^{34}$

The machinery of the public school also makes a substantial contribution to the operation and success of released time. Time and labor of teachers and school officials is required to administer the program. They must obtain and file cards of excused children; prepare, distribute, and keep current lists for classroom teachers of released time students; supervise an additional classroom dismissal; and secure and check absence reports of religious centers. $^{35}$ Some teachers, despite the Board of Education's prohibition of comment on the attendance or non-attendance of pupils at religious classes, 0 encourage children to attend religious classes or actually recruit them for such instruction. ${ }^{37}$ The persistence of this practice over the years, ${ }^{88}$ despite

Commissioner of Education. See note 20 supra. In operation, the regulations are cxtensively disregarded and many schools enforce the truancy laws as the schools in other districts. Affidavits of Henrietta Birman (teacher), Maurice Dawkins (tcacher), Wendy Gluck (student), Affidavits, King County Clerk's Number 10327/1948, Supremo Court of the State of New York, County of Kings. Also Public Educstion Associntion, Relased Time for Religious Education in New York City Schools 6-7 (1943) ; same title, (1945), at 7; same title, (1949), at 22-3.

33. On the pressure which any law exerts toward conformity see DICEY, LECTUnES on the Relations between Law and Public Opinion in England During the NinuTeEnth Century 465 (1941); Maslow, Prejudice, Discrimination and the Late, 275 Annals 9 (1951); Polier, Law, Conscience, and Society, 6 Law. Guild Rev. 490 (1946).

34. "Pupils compelled by law to go to school for secular education are released in part from their legal duty upon the condition that they attend the religious classes. This is beyond all question a utilization of the tax established public school system to aid religious groups to spread their faith. And it falls squarely within the ban of the First Amendment. . ." Black, J., Illinois ex rel. MeCollum v. Board of Education, 333 U.S. 203, 209-10 (1948). See also id. at 212, 227.

35. Affidavits of Leona Abrams (teacher), Henrietta Birman (teacher), Maurice A. Dawkins (teacher), William Hendrie (principal), Minnie Sutro (teacher), Affidavits, Kings County Clerk's Number 10327/1948, Supreme Court of the State of New York, County of Kings. See also Public Education Association (1943), op. cit. supra note 32 , at $6,8,9$; same title, (1945), at 8-9, 10; same title, (1949), at 12, 14-16, 18.

36. Rule 6, Board of Education, City of New York, op. cit. supra note 20.

37. Examples of this type of coercion are: "Miss Jeffries (a teacher) distributed blank consent cards to the children in her class and asked the children publicly for a show of hands of those who were going to participate in the released time program. . . Miss Jeffries scolded those students who had participated in the released time program the term before but who did not raise their hands to show that they were continuing." Affidavit of Wendy Gluck, Affidavits, Kings County Clerk's Number 10327/1948, Supreme Court of the State of New York, County of Kings. "A student in her class became ill and vomited in the classroom. Miss Jeffries said to the sick student that she did not object at looking at the vomit as much as she objected to looking at the student's face because he did not participate in the released time program." Affidavit of Esta Gluck, ibid. See also affidavit of Anne Stewart and Public Education Association (1943), op. cit. supra note 32 at 7-8; same title, (1945), at 15; same title, (1949), at 13, 17-18, 28.

38. Influencing of children by teachers appeared in the 1943, 1945, and 1949 studies of the Public Education Association. See note 37 supra. 
its prohibition, suggests that this is an abuse inherent in the program. ${ }^{30}$ The teacher exerts considerable influence on the children, ${ }^{40}$ and her contribution to the religious education program can be important.11 Moreover, high schools aid the released time program by allowing scholastic credit for religious instruction. ${ }^{2}$

Further state aid for religion exists in the substantial contribution made by the school milieu to the recruitment of children for religious classes. The public school environment is a significant factor in motivating behavior, ${ }^{43}$

39. It is important to study the actual practice since there are indications that the rules are not always literally followed. Rule 4 of the New York City Board of Edueation's Regulations before September 24, 1941 read, "Pupils of any grade will be dismissed from school for the last hour of each week, except that in classes on a departmental schedule release will be limited to the last period of the program." Mr. William Hendrie, who was then a principal in a school employing the departmental schedule, released his children at 2:30 as instructed by the regulation. Mr. Jansen, then Associate Superintendent of Schools and now Superintendent of Schools called and told Mr. Hendrie not to interpret the rules literally and to dismiss the students in the departmentally scheduled classes promptly at 2:00 p. m. Affidavit of Mr. William Hendrie, Kings County Clerl's Number 10327/1948, Supreme Court of the State of New York, County of Kings.

40. See National Education Assoctation, Departinent of School Priscipals, Personality Adjustarent of the Elendentary School Chilo 385 (1936); Carrington, Teacher Personality as a Factor in Child Adjustment. N.minowal Evucstro: Associntion of the United States. Departurent of Elemientary School Pri:cipals 15tur YEAREOOK 586-94 (1936).

41. Another, though more infrequent, practice used by teachers to induce attendance at the released time program is the giving of onerous work to the children who remain in the public school. A student reports, "My sixth grade teacher, Miss Croft, urged the children in the class to participate in the released time program and she stated that those students who did not participate would be required to do long division arithmetic problems during every released time hour, whereas those children who did participate were to ba excused from this exercise. While I was in Mriss Croft's class, the students who remained in the public school after 2 o'clock on Thursdays were given long division arithmetic problems beyond the level of the normal expectation of sixth grade." Affidavit of Anne Stewart, Affidavits, Kings County Clerk's Number 10327/1948, Supreme Court of the State of New York, County of Kings. Also Affidavit of Mirs. Gussie Finer, ibid. See Public Educatton Association (1943) op. cit. stpra note 32, at 13; same title, (1945), at 16; same title, (1949), at 23-4.

42. Credit is allowed for released time religious instruction on the basis of one-fourth unit per year. A maximum of one unit is allowed. A total of 248 schools in New Yorls State are receiving credit on this basis. The number of religious groups participating are: Jewish 9; Protestant (27 different affiliations) 75; Roman Catholic 162; other 2. Communications from George $\mathrm{K}$. Stone, Acting Chief, Bureau of Curriculum Development, Division of Secondary Education, University of the State of New York to Yale Law Journal dated November 20,.1951, and December 10,1951, on file in the Yale Law Library. A study of released time programs in high school indicates that one of the principal motivations for students to take released tume courses in high school was to obtain credit toward graduation. MeClure, Wcelsday Religions Educations at the High School Level, 46 Religrous Educition 345, 352 (1951).

43. For a description of the school environment and its impact on the individual see: Bossard, The Sociology of Chind Detelopsent $459-92$ (1948); Lee \& Lee, Tae Child and His Curriculum 74, 95-103 (2d ed. 1950); Waller, Tue Soctology of TEACHING C. 2 (1932). 
and it must be considered in evaluating the total contribution of the school, as an institution, ${ }^{44}$ to religious education. ${ }^{45}$ Holding religious classes during school hours aids religious instructon since it can more easily compete with classroom time than with recreational time. ${ }^{46}$ Such encouragement may be lessened in some schools because the released time period activities may be enjoyable, ${ }^{47}$ or may include important school work ${ }^{48}$ which the children may not want to miss. ${ }^{49}$ In addition, group interactions are an effective assistance to recruitment of children for religious classes and this has been regarded as "state action" in aid of religion. ${ }^{.0}$ Children belong to social groups not ordinarily based on religion or released time attendance..$^{61}$ Studics

44. Willard Waller finds five characteristics which are common to all kinds of schools and set them apart as social unities: (1) They have a definite population; (2) they have a clearly defined social structure, arising from the mode of social interaction pectiliar to the school; (3) they represent a compact network of social relationships; (4) they are pervaded by a we-feeling; and (5) they have a culture which is definitely their own. Reported in BosSARD, op. cit. supra note 43, at 460 .

45. Environment factors were expressly considered in the $\mathrm{McCollum}$ case. Illinois ex rel. McCollum v. Board of Education, 333 U.S. 203 (1948), especially at 227 n. 18.

46. Fuld, J., (dissent), Zorach v. Clauson, 303 N.Y. 161, 188 (1951); see also Note, 57 Y ALE L. J. 114, 119 (1948).

47. A few of the classes during the released time period include such subjects as handwork, auditorium, plays, and canteen. Public Education Association (1949), op. cit. supra note 32 , at 24 . See also note 41 supra.

48. This is despite regulations of the New York City Board of Education instructing teachers not to give new work in the released time period. New York City Board of Education General Circular No. 1 (1948-49). That new work is given in some classes sec: Public Education Association (1949), op. cit. stipra note 32, at 24 (8 classes of 243 reported).

49. Sometimes children would rather remain in public school. Puduc Education Association (1945), op. cit. sitpra note 32, at 16. Affidavits of Maurice Dawkins (teacher), and William Hendrie (principal), Affidavits, Kings County Clerk's Number 10327/1948, Supreme Court of the State of New York, County of Kings.

50. In the McCollum case Justice Frankfurter's concurrence, which had the support of three other Justices, considered the effect of the group on the individual as one of the elements of prohibited state aid to religion. "The law of imitation operates, and nonconformity is not an outstanding characteristic of children. The result is an obvious pressure upon children to attend." 333 U.S. 203, 227 (1948). Justice Frankfurter added, "The momentum of the whole school atmosphere and school planning is presumably put behind religious instruction, as given in Champaign, precisely in order to secure for the religious instruction such momentum and planning." 333 U.S. 203, 230-1 (1948). Sec also $i d$. at $227 \mathrm{n}$. 18. Of course all group pressure in a community would not be state action. Only that which occurs in the framework of a state operated institution can be said to be a part of that institution. Group pressure of school children is a part of the school as a social institution. See note 44 supra.

51. Group unity forms among children in the early primary school. HurLock, Critw Development 236 (1942); Thorpe, Child Psychology and Develapment 558 (1946). The primary bases for friendship formation of primary school children are: propinquity of the children, same mental and physical age. Hurlock, op. cit. stipra at 247; Munpiry, Murphy, \& Newcomb, Experumental Social Psychology 513 (1931); Thorre, op. cit. supra at 595 . 
have shown that a group influences children so strongly that they frequently accept its judgment even when they know that judgment is wrong, and in matters of opinion, children follow their friends almost completely. ${ }^{63}$ Thus, when a child in the public school sees his friends leave to attend religious classes, the social interactions of the school, as an institution, impel him toward religious instructon. When parents refuse to allow children to attend religious classes with their friends, the children may become emotionally disturbed. ${ }^{54}$ This reaction indicates the coercion on the children to attend religious classes. Such coercion, even though not completely successful in forcing conformity in all situations, was regarded in the 34 Collum case as one of the abridgments of the separation doctrine. ${ }^{\text {b }}$

52. Children were asked to judge which of three lines was the shortest. When not subject to control of the group they were able to give correct answers $93 \%$ of the time. Faced with the group pressure the correct answers of children 7-10 years old dropped to $43 \%$, and the correct answers of children 10-13 dropped to $54 \%$. 93\% of the younger children and $80 \%$ of the older children were affected by the group. Children commenting on the test said: "I felt funny. I know it will be silly, but when they said an answer and I didn't think it was right, I felt like my heartbeat went down." "I had a funny feeling inside. You know you are right and they are wrong, and you agree with them." Berenda, Influence of the Group on the Judganent of Chmiren 14-32 (1950). On the strong control of the peer group see, Brown, Socrology of Cannmood 164, 169-70 (1939) ; Bossard, op. cit. supra note 43, at 504, 507; HunLock, op. cit. supra note 51 at 218, 233, 236-7; LEE \& LEE, op. cit. sitpra note 43 , at 74.

53. In a test of food preferences there was virtually complete identification of choices between close friends. Duncker, Experimental Mfodification of Childres's Food Preference Through Social Suggestion, 33 Jour of Absoraral and Sochas Psycuology 489 (1938). Cf. Riesuran, The Lonely Crowd (1950).

54. A former non-released student describes her experiences as follows: "When the released time children departed at 2:00 p. m. on Wednesdays, I felt left behind. The released children made remarks about my being Jewish and I was made very much aware of the fact that I did not participate with them in the released time program. I endured a great deal of anguish as a result of this and decided that I would like to go along with the other children to the church center rather than continue to expose myself to such embarrassment. I asked my mother for permission to participate in the released time program to accompany my Catholic classmates to their religious center, but she forbade it. The divisiveness created by the released time program among the public school children became a part of our after school play. Following the introduction of released time at P.S. 163, Brooklyn, I began to notice I was ostracized by other children in after school activities. I was not permitted to share in their play, and they made unflattering remarks about my not going to the church center because I was Jewish. As a result of arguments about my nonparticipation in released time, my classmates called me such names as 'Christ killer' and 'dirty Jew.' I still live in the same neighborhood and to this day I do not talk to many of the girls with whom I went to school because of the arguments and fights which developed among us as a result of our differences which developed from the released time program." Statement of Leah Cunn, Affidavits, Kings County Clerk's Number 10327/1948, New York Supreme Court, County of Kings. See also affdavits by Gussie Finer and Charles Stewart, ibid.

55. Illinois ex rel. MicCollum v. Board of Education, 333 U.S. 203, 227-8, 230-1 (1948). See note 50 supra. 
The invalidation of the New York released time program is suggested by this analysis. The impairment of the free exercise right would be less than the impairment of the no-aid principle represented by the quantum and effects of the state aid to religion found in the released time system. But whatever decision may finally be reached after an analysis of the foregoing type, this method provides the most satisfactory means of making a constitutional determination in situations embodying a conflict in the First Amendment's religious clauses. 